\title{
Influence of the Welding Process on the Change of Mechanical Properties in the HAZ of Welds at Alloy AW 6005 and Possibilities of Their Renewal by Heat Treatment
}

\author{
Iva Novakova $^{1}$, Jaromir Moravec ${ }^{1}$, Martin $\mathrm{Svec}^{1}$, Tomas Kik ${ }^{2}$, David Korecek ${ }^{1}$ \\ ${ }^{1}$ Technical University of Liberec. Studentská 2, 46117 Liberec 1. Czech Republic. E-mail: iva.novakova@tul.cz \\ ${ }^{2}$ Silesian University of Technology, Welding Department, Konarskiego 18A, Gliwice, Poland
}

\begin{abstract}
This paper deals with monitoring the influence of welding on the mechanical properties degradation in HAZ of welds at aluminium alloy AW 6005 and also with assessing the possibility of utilization the heat treatment to minimize these effects. Workpieces from alloy AW 6005 are mostly supplied in aged state. After application of the temperature cycles during welding, there is a very intensive decrease of the mechanical properties in HAZ. The mechanical properties of the weld metal, HAZ and parent material were evaluated by means of the Vickers hardness. Moreover, influence of annealing and artificial aging on the final mechanical properties of the parent material was also evaluated. Based on the results, there were chosen the relevant heat treatment parameters, which were subsequently applied in order to recover the mechanical properties of welds in the HAZ.
\end{abstract}

Keywords: AW 6005, Welding, HAZ, Heat Treatment, Hardness

\section{Introduction}

In the last years, there are increasing demands on the constructions in light of weight reduction while maintaining sufficient strength. That is why hardenable aluminum alloys are also applied. These requirements are taken into account especially in automotive, transportation or e.g. production of railway vehicles. The knowledge of mechanical properties change in the area of the weld joint is important due to strength design of the welded constructions and due to prediction its behavior under subsequent loading. The constructional blanks made from hardenable alloys (including used AW 6005 alloy) are in the most cases supplied in the state after hardening. The most used welding methods for aluminium and its alloys are arc welding in the atmosphere of inert gas by MIG or TIG method.

The significant decrease of mechanical properties in the heat-affected zone (HAZ) is observed during welding of hardenable aluminium alloys by fusion methods. Degradation of mechanical properties is more pronounced with increasing thickness of welded materials. The reasons for it are applications of multiple temperature cycles and the need of preheating. The hardening phases are gradually dissolved when material is heated above $200^{\circ} \mathrm{C}$ where strength and hardness of the welded material are changed (depends on reached temperature) up to values of annealed material. [1,2] The decrease of the welded joint mechanical properties can be eliminated by application welding methods with a high temperature gradient and limited heat input. [2] As another possibility there is usage of welding methods with a working temperature below melting point of alloy or below temperature of hardenable alloys stability, even. to perform curing heat treatment after welding. [3]

Another problem with welding of hardenable aluminium alloys is their susceptibility to hot cracking. In practice, the non-hardenable filler materials are used for welding of hardenable aluminium alloys due to elimination tendency to hot cracks creation in the weld metal. The influence of hydrogen, which causes porosity of the weld metal, may also be reflected in the quality of the welds. The formation of hydrogen-initiated cracks can also appear in rare cases. The hydrogen effect is usually eliminated by using high purity shielding gases containing at least 99.99 wt. \% of Ar. [1]

The applicability of these types of welds is primarily in the area of passenger rail transport in the construction of car bodies. The research was carried out for VÚKV a.s. The aim of this paper is to show the effect of multiple MIG welding method on the degradation of mechanical properties in HAZ of AW 6005 alloy and the assessment of application heat treatment to minimize these negative effects.

\section{The effect of multiple temperature cycle on the mechanical properties of AW 6005 alloy}

Aluminium alloy EN AW 6005 (AlSiMg) was used in the experiment. The material was supplied in the form of extruded L-profiles with the thickness of $10 \mathrm{~mm}$ and in T6 state. The chemical composition of used alloy was determined by Q4Tasman spectrometer (see Tab. 1).

The two-layer welding experiment was designed for a material of thickness $10 \mathrm{~mm}$. The aim was to determine the change of mechanical properties in HAZ after each welding cycle and to define the influence of applied multiple temperature cycle on these properties in dependence on time and distance from fusion line. The weld geometry was designed as a welding with washer (the washer has a root face of $1.5 \mathrm{~mm}$ in this case) - see Fig. 1. The total sample size for welding was $200 \times 250 \times 10 \mathrm{~mm}$. The root weld bead was done in its full length and the second weld bead was done only into $3 / 5$ of length for assessment the effect of partial heat influence from each weld bead. The initial $40 \mathrm{~mm}$ of the weld could not be used for evaluation because of heat saturation. The preheating is required for welding of larger thicknesses due to heat removal high rate. Therefore, the effect of preheating was also evaluated in the experiment.

The manual MIG welding method was used. The filler material was in form of OK Autrod 5087 (AlMg5) wire 
with diameter of $1.2 \mathrm{~mm}$. As a shielding atmosphere there was Ar with purity 4.9 and flow rate 15 l.min-1. The used filler material is non-hardenable (commonly used for welding $\mathrm{Al}-\mathrm{Si}-\mathrm{Mg}$ alloys) to prevent hot cracks formation in the weld metal. All process parameters for all weld beads were monitored by WeldMonitor and they are listed in Tab. 2 both for non-preheated weld (marked as weld 1) and weld with preheating $90^{\circ} \mathrm{C}$ (marked as weld 2).

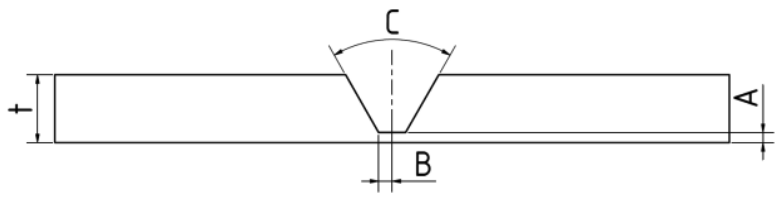

Fig. 1 The geometry of weld surface: $A=1.5 \mathrm{~mm}, B=2$ $\mathrm{mm}, \mathrm{C}=60^{\circ}, t=10 \mathrm{~mm}$.

Tab. 1 Chemical composition of AW 6005 alloy (wt\%) - measured by Q4Tasman spectrometer

\begin{tabular}{|c|c|c|c|c|c|c|c|c|c|}
\hline $\mathbf{S i}$ & $\mathbf{F e}$ & $\mathbf{C u}$ & $\mathbf{M n}$ & $\mathbf{M g}$ & $\mathbf{C r}$ & $\mathbf{N i}$ & $\mathbf{Z n}$ & $\mathbf{T i}$ & $\mathbf{A l}$ \\
\hline $\mathbf{0 . 7 0 5}$ & 0.182 & 0.098 & 0.22 & 0.415 & 0.074 & 0.0031 & 0.015 & 0.033 & 98.16 \\
\hline
\end{tabular}

Tab. 2 The process parameters for multiple temperature cycle

\begin{tabular}{|l|c|c|c|c|c|c|}
\hline & $\begin{array}{c}\text { Weld } \\
\text { bead }\end{array}$ & $\begin{array}{c}\text { Welding } \\
\text { current } \\
\text { [A] }\end{array}$ & $\begin{array}{c}\text { Welding } \\
\text { voltage } \\
\text { [V] }\end{array}$ & $\begin{array}{c}\text { Welding speed } \\
\text { [m.min }\end{array}$ & $\begin{array}{c}\text { Wire feed speed } \\
\text { [m.min-1 }\end{array}$ & $\begin{array}{c}\text { Total heat in- } \\
\text { put } \\
\text { [kJ.cm-1] }\end{array}$ \\
\hline $\begin{array}{l}\text { Weld without } \\
\text { preheating } \\
\text { (Weld 1) }\end{array}$ & $\mathbf{n . 1}$ & 159.8 & 23.2 & 0.416 & 8.4 & 5.35 \\
\cline { 2 - 7 } & $\mathbf{n . ~ 2}$ & 181.1 & 26 & 0.186 & 10.2 & 15.19 \\
\hline $\begin{array}{l}\text { Weld with } \\
\text { preheating } \\
\text { (Weld 2) }\end{array}$ & $\mathbf{n . 1}$ & 150.2 & 22.8 & 0.429 & 7.6 & 4.79 \\
\cline { 2 - 7 } & $\mathbf{n . 2}$ & 162.4 & 24.4 & 0.17 & 8.2 & 13.99 \\
\hline
\end{tabular}

The thermal influence of the parent material leads to a decrease of mechanical properties. This change was monitored via hardness measurement by Vickers method HV5 (ČSN EN ISO 6507-1). To evaluate the effect of thermal influence on the material by each bead, the specimens were taken both from the single bead and from the two-layer weld from each welded plate (weld 1 and weld 2 ). In the case of samples with single bead, there was measured HV5 hardness in the weld material, in the HAZ and in the parent material with distance $4 \mathrm{~mm}$ (row 1) from the bottom of the sample. For two bead samples, the hardness was measured in two rows with a distance of 4 $\mathrm{mm}$ (row 1) and $7.5 \mathrm{~mm}$ (row 2) from the bottom of the sample (see Fig. 2). The center to center distance of the individual indents was $1 \mathrm{~mm}$ and $2 \mathrm{~mm}$ in a distance over $30 \mathrm{~mm}$ from the fusion line.

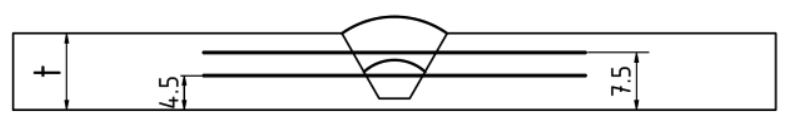

Fig. 2 The layout of hardness measurement areas

The results of HV5 hardness measurement in the weld metal, HAZ and the parent material for the weld without preheating (weld 1) are shown in Fig. 3 and for the weld with pre-heating (weld 2) in Fig. 4. The significant difference in HAZ width is evident from the hardness curves courses.

In the case of a weld without pre-heating (weld 1), the hardness in row 1 was reduced to $68 \mathrm{HV} 5$ (i.e. reduction by cca $38 \%$ in compare to the parent material) after welding the first bead with heat input $5.35 \mathrm{~kJ}_{\mathrm{cm}} \mathrm{cm}^{-1}$ and with of HAZ HAZ was $8 \mathrm{~mm}$ in this case. The heat input during welding of the second bead was $15.19 \mathrm{~kJ} \mathrm{~cm}^{-1}$ and in the same area of HAZ hardness decreased up to $60 \mathrm{HV} 5$ (it is reduction approx. by $45 \%$ in compare to the parent material). In this case, width of HAZ extended to $25 \mathrm{~mm}$ (see Tab. 3).

At weld with pre-heating (weld 2), the hardness in row 1 was reduced to 66 HV5 (it is about $40 \%$ reduction in compare to the parent material) after welding of the first bead. The heat input was $4.79 \mathrm{~kJ} . \mathrm{cm}^{-1}$ and width of HAZ was $9 \mathrm{~mm}$ in this case. The heat input during welding of the second bead was $13.99 \mathrm{~kJ} . \mathrm{cm}^{-1}$ and the hardness decreased up to 55 HV5 in the same area of HAZ (it is about one half reduction in compare to the original value - 110 HV5). Width of HAZ extended to $35 \mathrm{~mm}$. So pre-heating, which is required to reduce the cold weld cracking susceptibility, caused a reduction of HV5 hardness value in HAZ and it also extends this area in comparison to the weld without pre-heating (see Tab. 3).

From the measured courses is also evident that HV5 hardness decreased to 80 HV5 in the weld metal area. Different mixing of non-hardenable filler material OK Autrod 5087 with the hardenable parent material AW 6005 causes the differences in hardness of weld with and without pre-heating. Welding with pre-heating results in higher level of material mixing and the hardness reduction is more intensive. 


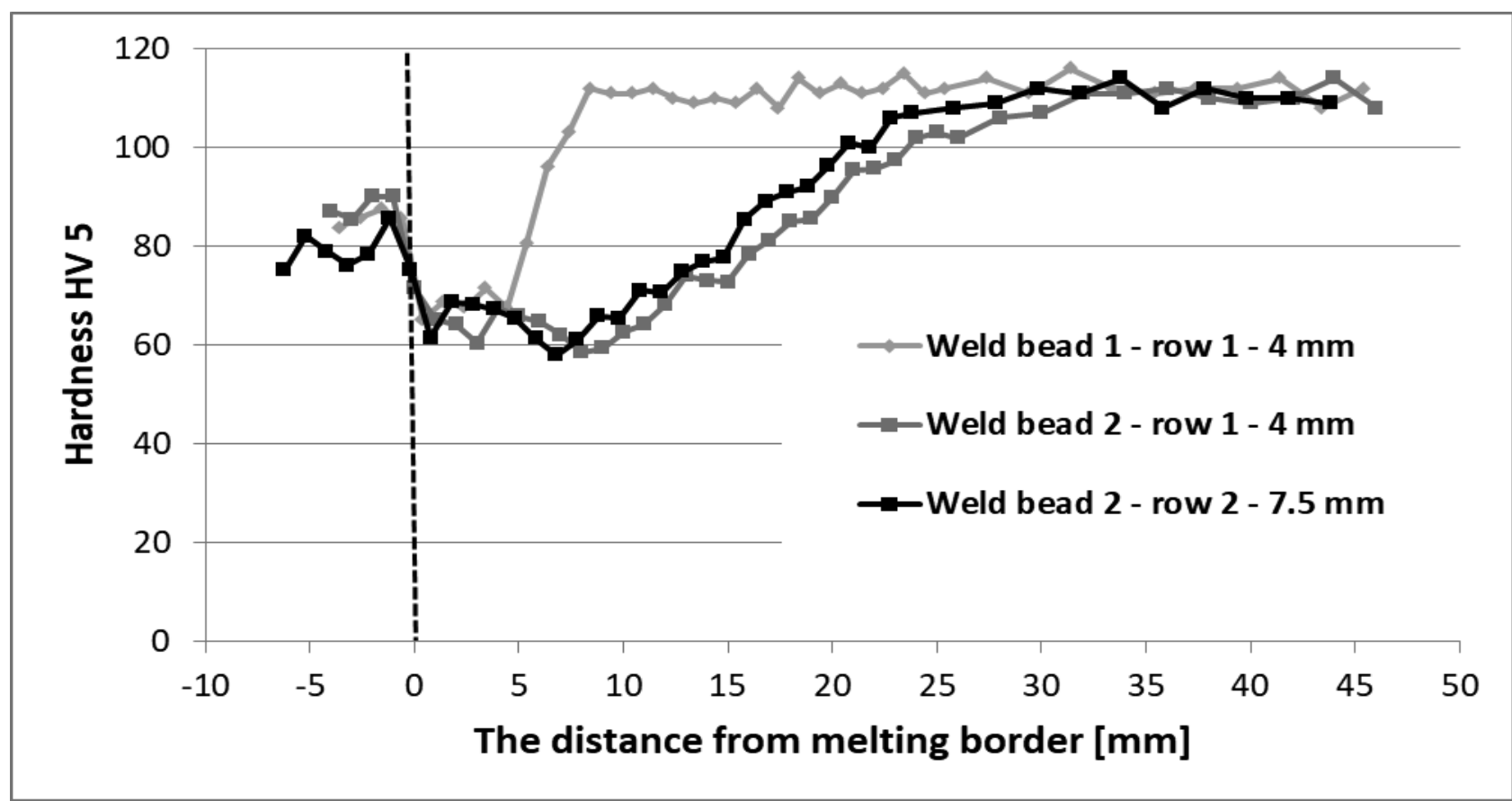

Fig. 3 Measured hardness values in weld metal, HAZ and parent material at weld 1 - without pr-eheating

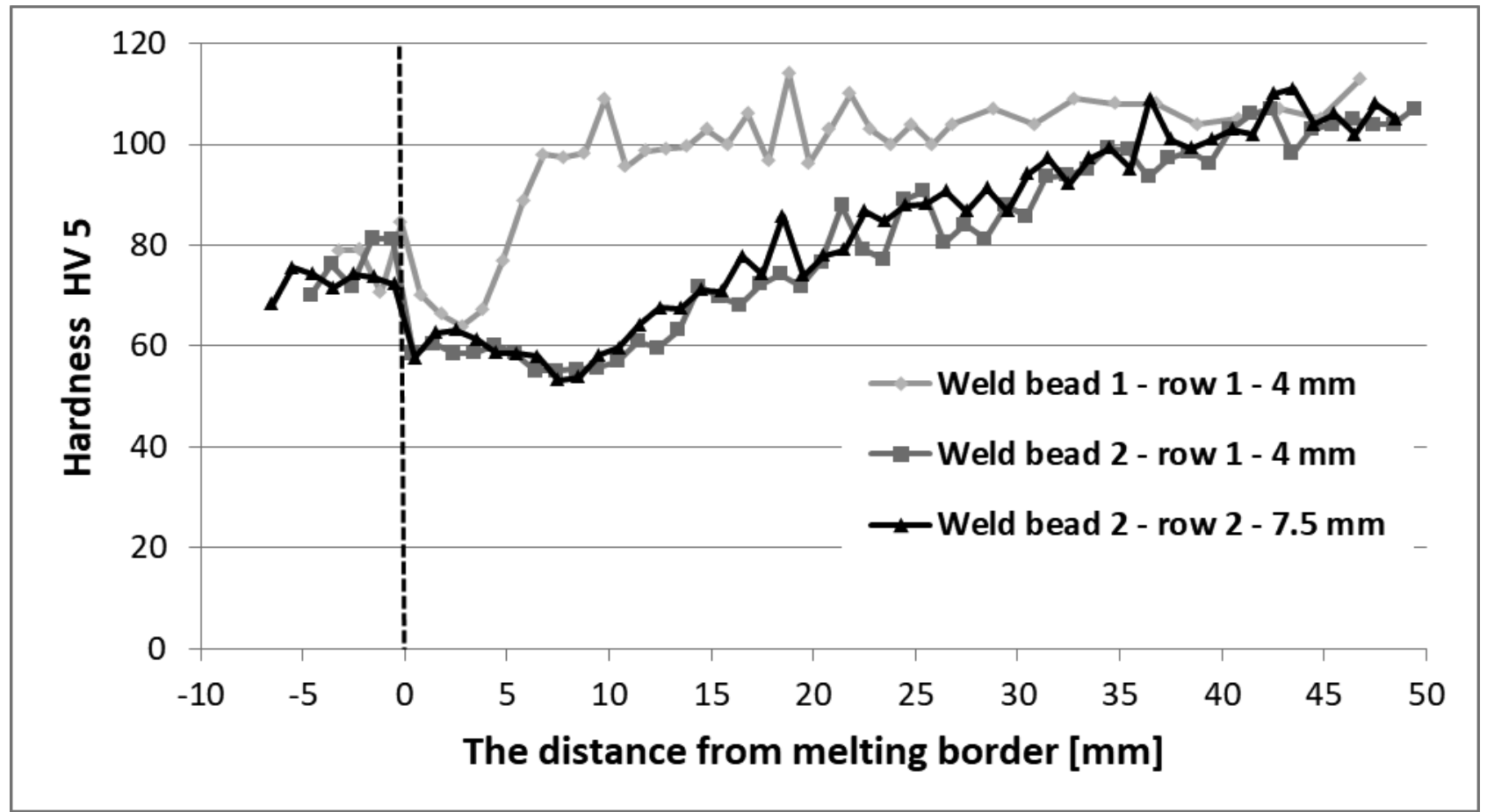

Fig. 4 Measured hardness values in weld metal, HAZ and parent material at weld 2 - with pre-heating

Tab. 3 Overview of heat input, hardness, hardness reduction for weld without and with pre-heating

\begin{tabular}{|l|c|c|c|c|}
\hline & Weld bead & Heat input [kJ.cm & Hardness [HV5] & $\begin{array}{c}\text { Hardness reduction } \\
\text { in comparison to } \\
\text { parent material } \\
\text { [\%] }\end{array}$ \\
\hline Parent material & - & 0 & 110 & 0 \\
\hline $\begin{array}{l}\text { Weld without } \\
\text { pre-heating (Weld } \\
\text { 1) }\end{array}$ & $\mathbf{n . 1}$ & 5.35 & 68 & 38 \\
\hline $\begin{array}{l}\text { Weld with } \\
\text { pre-heating (Weld } \\
\text { 2) }\end{array}$ & $\mathbf{n . 2}$ & 15.19 & 60 & 45 \\
\cline { 2 - 5 } & $\mathbf{n . 1}$ & 4.79 & 66 & 40 \\
\hline
\end{tabular}




\section{Heat treatment effect on the mechanical prop- erties of AW 6005 alloy}

The sharp decrease in hardness and thus also in mechanical properties of the welded joint is evident from the results of welding experiments. Therefore, as another aim there was to find the most suitable heat treatment parameters for processing welds so that the negative effect of welding would be eliminated as much as possible. For this reason, experiments focused on assessing influence of the solution annealing temperature (ageing temperature respectively) and the dwell time at this temperature on the parent material mechanical properties were performed. The $11016 \mathrm{~S}$ Clasic electric furnace with temperature tolerance of $\pm 10{ }^{\circ} \mathrm{C}$ was used for solution annealing and the Venticell Standart 404 furnace with temperature tolerance of $\pm 3{ }^{\circ} \mathrm{C}$ was used for precipitation hardening of samples.

Mechanical properties were evaluated by the Brinell hardness measurement - there was used $2.5 \mathrm{~mm}$ diameter ball and test load of $62.5 \mathrm{kp}(612.9 \mathrm{~N})$. The HPO 250 hardness tester with LabControl CCD software was used for hardness measurement. Tensile strength, yield strength and uniform ductility were also monitored for selected samples.

A lot of authors as e.g. [5, 6, 7, 8, 9, 10, 11] dealt with the effect of heat treatment on other types of alloys. Heat treatment parameters for AW6005 alloy were chosen in accordance with [4]. There are recommended following parameters: solution annealing temperature $545{ }^{\circ} \mathrm{C}$ for 1 hour, cooling into the water and subsequent ageing at 175 ${ }^{\circ} \mathrm{C}$ for 8 hours. The effect of solution annealing temperature $\left(530,545\right.$ and $560{ }^{\circ} \mathrm{C}$ for 1 hour, afterwards were samples cooled in water and aged at $175^{\circ} \mathrm{C}$ ) on HB hardness was monitored in the experiment - see Fig. 5.

Furthermore, there was monitored the influence of dwell time ( 1 and 2 hours) on solution annealing temperature as $545^{\circ} \mathrm{C}$, cooling in water $\left(25^{\circ} \mathrm{C}\right)$ and ageing at $175{ }^{\circ} \mathrm{C}$ on HB hardness values, see Fig. 5. The optimal parameters of solution annealing were selected as following: temperature $545^{\circ} \mathrm{C}$ for 1 hour.

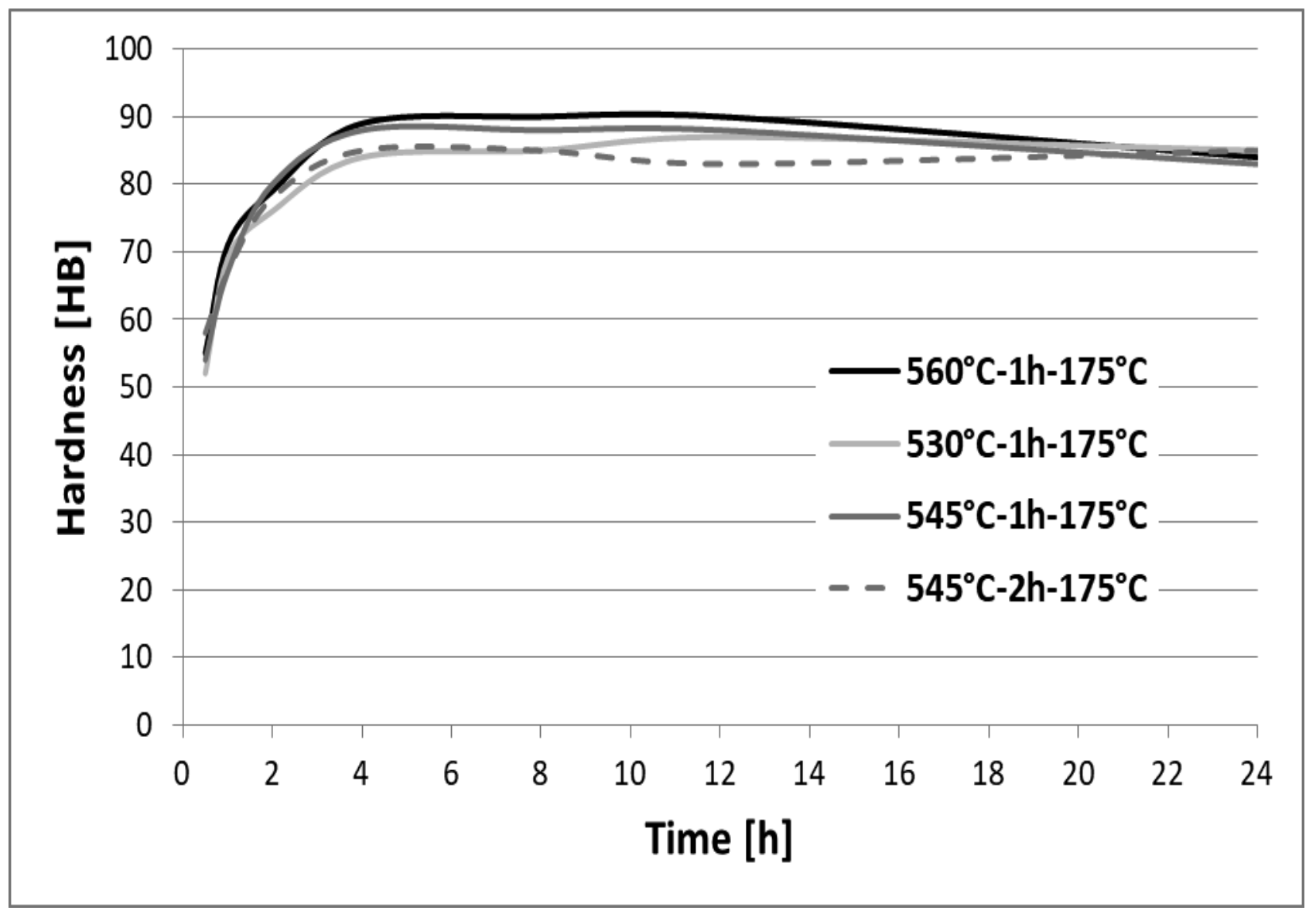

Fig. 5 Measured HB hardness values - solution annealing temperature $545^{\circ} \mathrm{C}$, dwell time 1 and 2 hours, cooling in water and after artificial ageing at temperature $175^{\circ} \mathrm{C}$

In addition to that, other experiments were performed to determine the appropriate temperature and ageing time. That is why hardness values were measured for samples annealed at temperature $545{ }^{\circ} \mathrm{C}$ for 1 hour, afterward cooled in water $\left(25^{\circ} \mathrm{C}\right)$ and subsequently aged at 160,175 and $190{ }^{\circ} \mathrm{C}$. The results are summarized in Fig. 6. The maximum HB hardness value was about $60 \mathrm{HBW}$ after natural ageing and there wasn't monitored any significant increase even after 72 hours of natural ageing. 


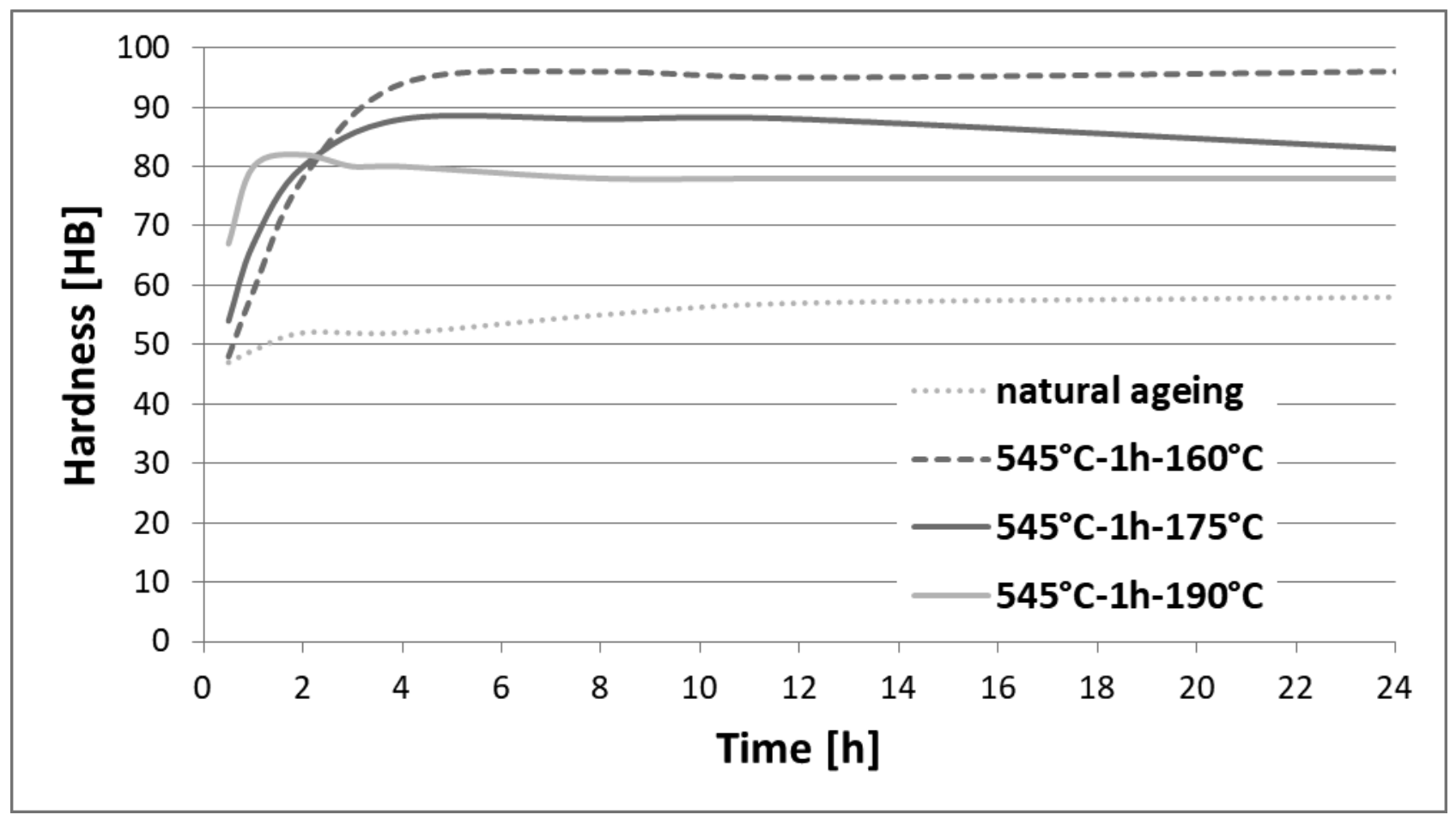

Fig. 6 Measured HB hardness values - solution annealing temperature $545^{\circ} \mathrm{C}$, dwell time 1 and 2 hours, cooling in water and after artificial ageing at temperatures 160,175 and $190^{\circ} \mathrm{C}$

From the results of experiments is evident that maximum hardness values were achieved after artificial ageing at temperature $160^{\circ} \mathrm{C}$ for 8 hours, at $175^{\circ} \mathrm{C}$ for 4 hours or at $190^{\circ} \mathrm{C}$ for 2 hours. However, the initial hardness of the parent material (105 HBW, 115 HV5) was not achieved under any combination of heat treatment parameters. This is due to the fact that the original structure, which was produced during manufacturing the profile by extrusion technology and its subsequent hardening T6, partially recrystallizes during heat treatment.

Fig. 7 shows EBSD maps of AW 6005 alloy in the base state (Fig. 7A) and after heat treatment - solution annealing at $545^{\circ} \mathrm{C}$ for 1 hour, afterwards cooled in water and aged at temperatures $160^{\circ} \mathrm{C}$ for 8 hours (Fig. 7B). From the EBSD map is obvious that the parent material (Fig. 7A) was delivered in the condition after rolling or drawing - one crystallographic direction (graphically represented by blue color) dominates in grain orientation. On the other hand, the material was partially recrystallized after heat treatment (Fig. 7B) resulting in a more pronounced anisotropy within the crystallographic directions orientation in the individual grains (graphically represented by the entire RGB scale).
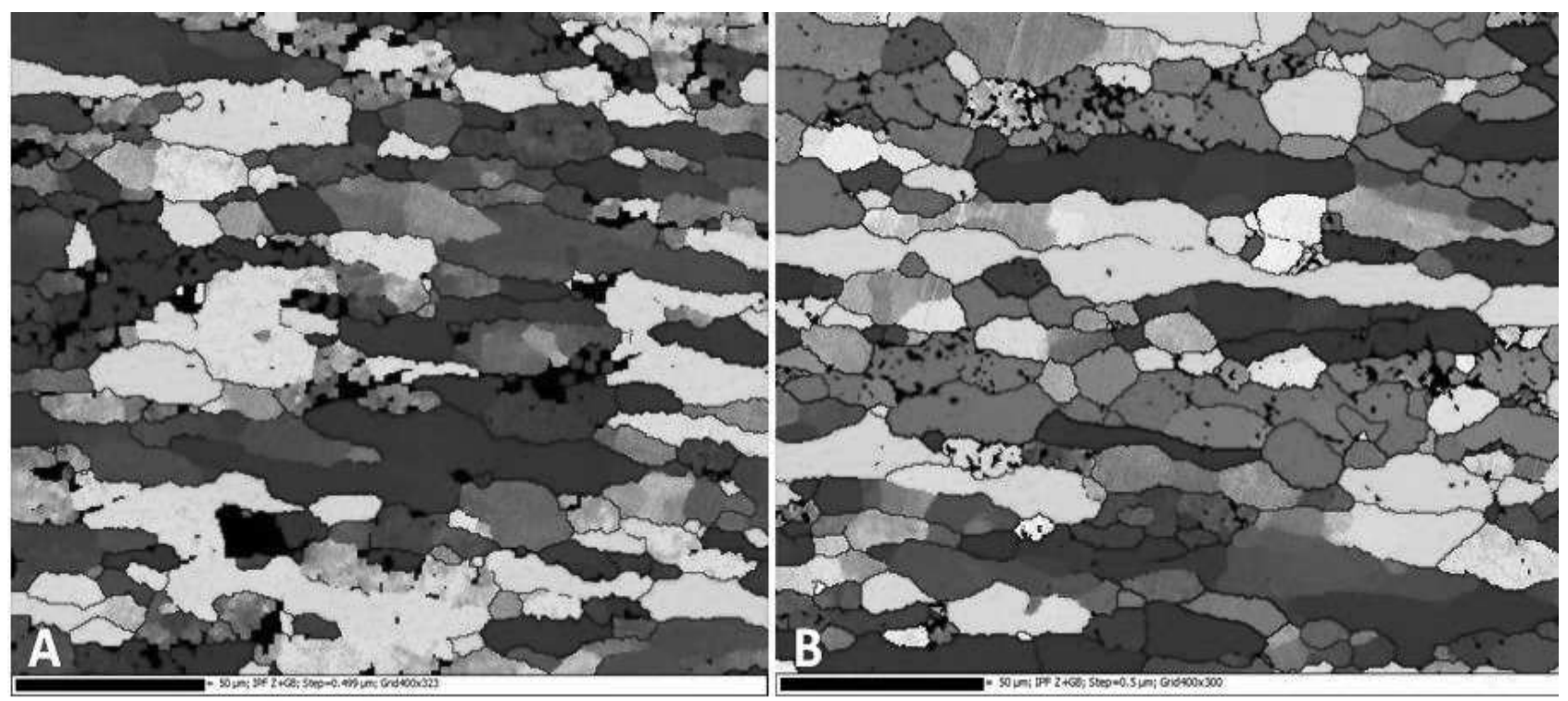

Fig. 7 EBSD map of AW 6005 alloy - parent material (Fig. 7A) and material after heat treatment - solution annealing at $545^{\circ} \mathrm{C}$ for 1 hour, afterwards cooled in water and aged at temperatures $160^{\circ} \mathrm{C}$ for 8 hours (Fig. $7 B$ ) 
The tensile test specimens were prepared from the basic material in accordance with ČSN EN ISO 6892-1 and heat treatment (solution annealing and aging) applied to them to achieve maximum hardness. Tensile test was performed on heat treated samples using TIRAtest 2300 (an evaluation of the measured data was performed in
Labtest software). The overview of tested samples and measured data (Rm, Rp0.2, Ag a A30) is shown in Tab. 4. The results of the experiment show that aging temperature of $160{ }^{\circ} \mathrm{C}$ for 8 hours seems optimal. Similar results reported also [5].

Tab. 4 Mechanical properties of parent material and material after heat treatment

\begin{tabular}{|c|c|c|c|c|}
\hline & $\mathbf{R}_{\mathrm{p} 0.2}[\mathrm{MPa}]$ & $\mathbf{R}_{\mathbf{m}}[\mathrm{MPa}]$ & $\mathbf{A g}_{\mathrm{g}}[\%]$ & A30mm [\%] \\
\hline Parent material & $291.9 \pm 10.16$ & $333.4 \pm 15.88$ & $7.4 \pm 0.60$ & $11.7 \pm 1.26$ \\
\hline $545^{\circ} \mathrm{C}-1 \mathrm{~h}$-cooling & 68.2. \pm 1.77 & $174.93 \pm 2.32$ & $21.7 \pm 3.07$ & $26.5 \pm 2.31$ \\
\hline $545^{\circ} \mathrm{C}-1 \mathrm{~h}-190^{\circ} \mathrm{C}-2 \mathrm{~h}$ & $269.7 \pm 4.30$ & $295.27 \pm 3.95$ & $5.5 \pm 0.05$ & $10.4 \pm 0.31$ \\
\hline $545^{\circ} \mathrm{C}-1 \mathrm{~h}-175^{\circ} \mathrm{C}-4 \mathrm{~h}$ & $292.2 \pm 3.01$ & $322.27 \pm 2.7$ & $7.3 \pm 0.45$ & $12.2 \pm 0.82$ \\
\hline $5^{2} 5^{\circ} \mathrm{C}-1 \mathrm{~h}-160^{\circ} \mathrm{C}-8 \mathrm{~h}$ & $298.2 \pm 0.89$ & $334.03 \pm 1.03$ & $7.3 \pm 0.49$ & $11.5 \pm 0.62$ \\
\hline
\end{tabular}

\section{The effect of heat treatment on the mechanical} properties restoration of AW 6005 alloy welded joint

Welding has significant effect on the change of the joint mechanical properties. It is necessary to apply solution annealing and then ageing at elevated temperature to restore the properties after welding. Based on the results of experiments performed on the parent material, the heat treatment with the parameters at which the highest hardness values were achieved, was applied. The solution annealing at $545^{\circ} \mathrm{C}$ for 1 hour was performed for all samples. The hardness values decreased for both weld types (without and with pre-heating) in HAZ and also in parent material up to about 45 HV5 after solution annealing.
Subsequently, the artificial ageing at $190^{\circ} \mathrm{C}$ for 2 hours, at $175^{\circ} \mathrm{C}$ for 4 hours and at $160 \mathrm{C}$ for 8 hours was performed. After that, the hardness (HV5) of weld material, HAZ and parent material was measured for all these samples by the same method as in the case of samples after welding - see Fig. 2.

The results obtained during manufacturing of twolayer weld are the most beneficial for the technical practice, because the effect of multiple temperature cycle is truly obvious from these results. Therefore, Fig. 8 (weld without pre-heating) and Fig. 9 (weld with pre-heating of $90^{\circ} \mathrm{C}$ ) show the hardness curves for samples with two weld beads in the area of row 1 (4 $\mathrm{mm}$ from the bottom of sample).

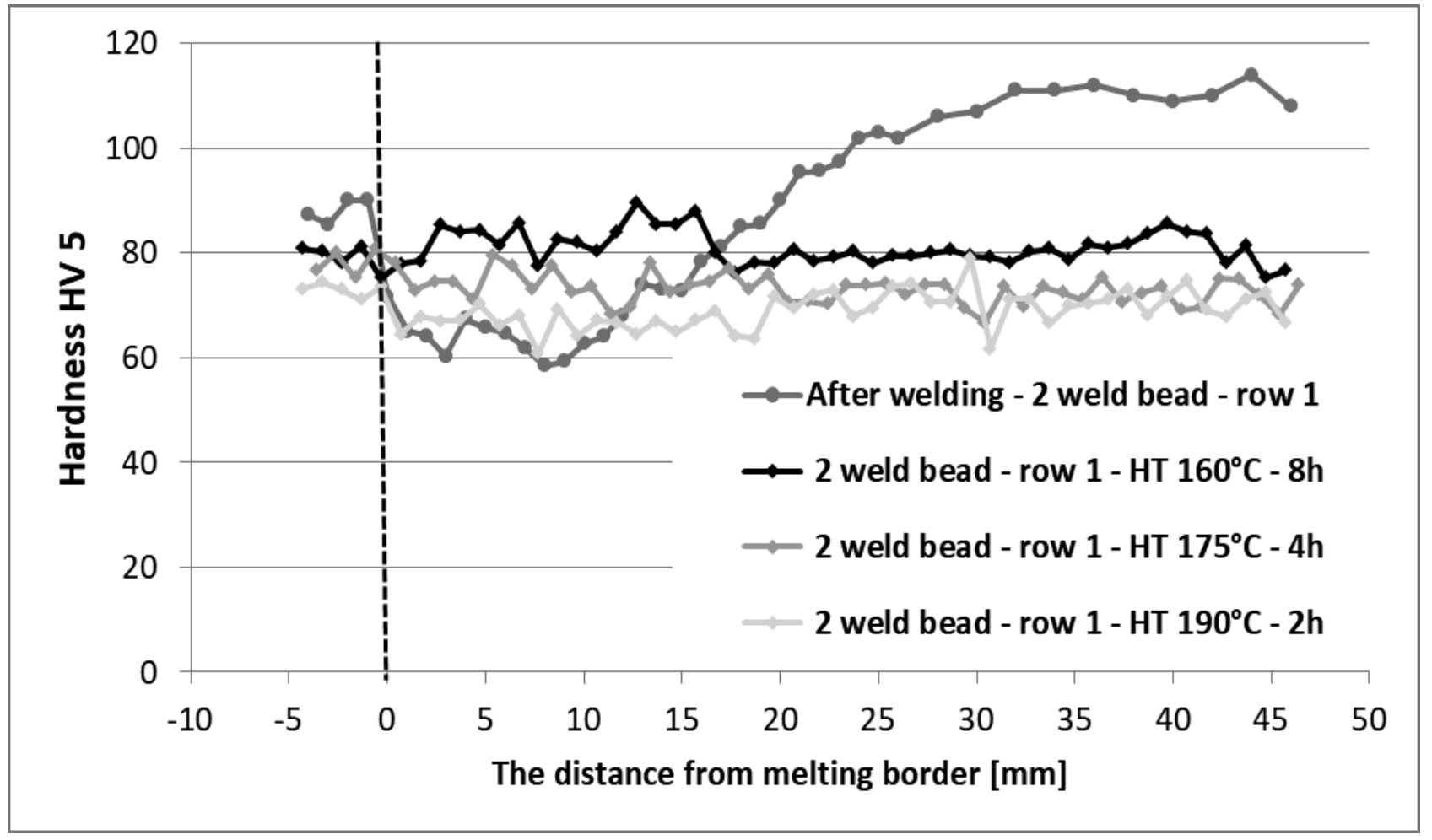

Fig. 8 Measured hardness values in weld metal, HAZ and parent material - after welding of the second weld bead without pre-heating and after heat treatment in the area of row 1 
It is obvious from the obtained results, that only very small variations in the hardness values (within range of 10 HV5) caused by the use of non-hardenable additional material are in the region of weld metal. The intensity of mixing with the parent material is not sufficient to achieve the mechanical properties of parent hardenable material in this area as well. The highest increase in the parent material and HAZ hardness values occurred after ageing at temperature $160^{\circ} \mathrm{C}$ for 8 hours - see Fig. 8 and 9.

In the case of weld without pre-heating (see Fig. 8), which was artificially aged at $160^{\circ} \mathrm{C}$ for 8 hours was measured increase of hardness in HAZ and its decrease in the parent material - i.e. hardness distribution revealed higher uniformity between HAZ and parent material. The hardness in HAZ and parent material of welded sample is around 80 HV5 (i.e. improved approx. by $25 \%$ compared to the state after welding). On the other hand, the increase in the hardness values was the smallest after ageing at $190^{\circ} \mathrm{C}$ for 2 hours - hardness was about 68 HV5 (i.e. improvement approx. by $12 \%$ compared to the state after welding).

Result for welding with pre-heating after solution annealing revealed the same hardness decrease in HAZ and parent material as in the case of weld 1 without pre-heating. After artificial ageing were measured higher hardness values than in the weld without preheating. The greatest increase in hardness of the parent material and HAZ was observed by using the same ageing condition as in the case of weld 1 - i.e. at $160{ }^{\circ} \mathrm{C}$ for 8 hours (see Fig. 9). Almost the same increases in hardness values were measured for both ageing conditions - temperature $175^{\circ} \mathrm{C}$ for 4 hours and temperature $190^{\circ} \mathrm{C}$ for 2 hours (see Fig. 9). Hardness values varied around 80 HV5.

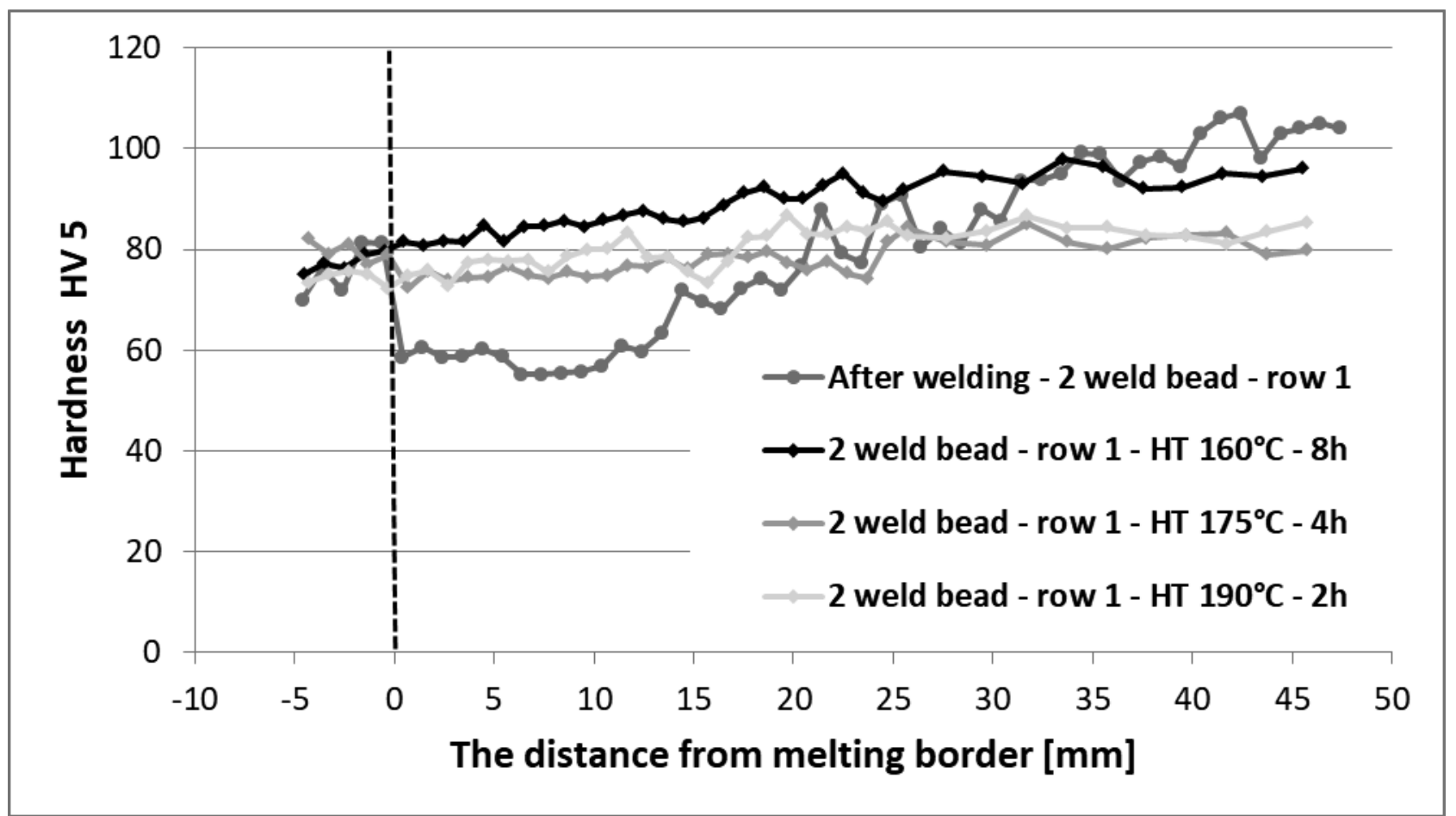

Fig. 9 Measured hardness values in weld metal, HAZ and parent material - after welding of the second weld bead with pre-heating of $80^{\circ} \mathrm{C}$ and after heat treatment in the area of row 1

\section{Conclusion}

The hot cracks susceptibility of the weld metal and significant decrease of mechanical properties in HAZ is very necessary to be taken into account when designing procedures for welding constructions from hardenable aluminium alloys. However, these disadvantages can be partially eliminated by the suitable heat treatment. In technical practice, hardenable alloys are commonly welded with respect to elimination the hot cracks formation by a non-hardenable filler material, even at the cost of lower weld metal strength properties.

At welding materials with higher thickness (i.e. at multilayer welds), the pre-heating of parent material is necessary considering the heat dissipation intensity from the weld area. Pre-heating reduces the probability of creation cold joint defects but it extends HAZ at the same time. However, suitable heat treatment can restore mechanical properties in HAZ to a certain extent.

Several recommendations can be made based upon the performed experiments and measured results. Welding has a very significant effect on the change of mechanical properties in HAZ. This effect is related with the material thickness. Higher thicknesses require multiple temperature cycles and pre-heating. Due to the utilization of non-hardenable filler materials and regarding limited possibilities of subsequent heat treatment, great attention should be paid already to the design of weld joint. Welds should be located outside from areas of maximum loads and they should be designed so that to eliminate the specific heat input as much as possible. This is also closely related to the weld joint assembly accuracy. The higher weld gap, the higher specific heat input.

In the case of application the heat treatment for the 
multiple welding of the hardenable aluminium alloy AW 6005 with the filler material of AlMg5 type, it is recommended to apply solution annealing at $545^{\circ} \mathrm{C}$ for 1 hour that is followed by ageing at $160^{\circ} \mathrm{C}$ for 8 hours. The mechanical properties of the welded joints are restored most effectively by this way.

\section{Acknowledgement}

This publication was written at the Technical University of Liberec as part of the project SGS 21280 "Research and development for innovation of materials and production technologies with application potential in mechanical engineering" with the support of the Specific University Research Grant, as provided by the Ministry of Education, Youth and Sports of the Czech Republic in the year 2019.

\section{References}

[1] Kolektiv autorů. (2001). Materiály a jejich svařitelnost. pp. 233 - 240. Ostrava: ZEROSS. ISBN 80-85771-85-3.

[2] SAHUL, M., TURŇA, M., ŠUGÁROVÁ, J. a SAHUL, M. (2013). Influence of laser welding aluminium alloy on mechanical properties of welded joints. In: Manufacturing Technology, Vol. 13, No. 4, pp. $526-530$.

[3] KOLÁ̌̆, V. Svařitelnost hlinikových slitin [online]. [cit. 2015-10-25]. Dostupné z www: <http://www.cws-anb.cz/t.py?t=2\&i=502>.

[4] MICHNA, Š. a kol. (2005). Encyklopedie hliniku. pp. 119 - 228. Prešov: ADIN. ISBN 80-89041-884.

[5] KUČERA, V., VOJTĚCH, D. (2017). Influence of the Heat Treatment on Corrosion Behaviour and Mechanical Properties of the AA 7075 Alloy. In:
Manufacturing Technology, Vol. 17, No. 5, pp. 747-752.

[6] KOVAlČÍK, T., STOUlil, J., SLÁMA, P., VOJTĚCH, D. (2015). The Influence of Heat Treatment on Mechanical and Corrosion Properties of Wrought Aluminium Alloys 2024 and 6064. In Manufacturing Technology, Vol. 15, No.1, pp. 54-61.

[7] LUŠTINEC, J., OČENÁŠEK, V., JELÍNEK, M. jr. (2017). The Effect of Homogenization Parameters on the Structure of EN AW-6082 Alloy. In Manufacturing Technology, Vol. 17, No.5, pp. 766-772.

[8] MRÓWKA-NOWOTNIK, G., SIENIAWSKI, J. (2005). Influence of heat treatment on the microstructure and mechanical properties of 6005 and 6082 aluminium alloys. In: Journal of Materials Processing Technology, Vol. 162-163, May 2005, pp. 367-372.

[9] RIEDL, L. (2015) Vliv umělého a přirozeného stárnutí na mechanické vlastnosti svarů u vytvrditelných slitin hliníku AW 6082. [Diplomová práce]. Liberec: Technická univerzita v Liberci Fakulta strojní.

[10] MORAVEC, J., I. NOVÁKOVÁ a J. BRADÁČ. (2016) Effect of age hardening conditions on mechanical properties of AW 6082 alloy Welds. In: Manufacturing Technology. Vol. 16, No. 1. , pp. $192-198$.

[11] SOLFRONK, P., SOBOTKA, J., KOLNEROVÁ, M., KOREČEK, D. (2017) Thermal treatment Influence on the Change of Alloy EN AW-6082 Mechanical Properties. In: Manufacturing Technology, Vol. 17, No. 5, pp. 848-853. 